\title{
HUBUNGAN SKOR MODIFIED SEQUENTIAL ORGAN FAILURE ASSESSMENT (MSOFA) DENGAN KEJADIAN VENTILATOR ASSOCIATED PNEUMONIA (VAP) PADA PASIEN YANG TERPASANG VENTILATOR
}

\author{
Hetty Yuliana ${ }^{1}$, Hellena Deli ${ }^{2}$ Agrina $^{3}$ \\ ${ }^{1}$ RSUD Puri Husada Tembilahan, \\ ${ }^{2,3}$ Fakultas Keperawatan Universitas Riau Jalan Pattimura No.9 Gedung G Pekanbaru Riau \\ Email: hetty.yuliana82@gmail.com
}

\begin{abstract}
Abstrak
Kegagalan multi organ pada pasien dirawat di ICU dapat meningkatkan terjadinya Ventilator Associated Pneumonia (VAP). Tujuan penelitian ini untuk melihat hubungan skor Modified Sequential Organ Failure Assessment (MSOFA) dengan kejadian VAP pada pasien yang terpasang ventilator. Desain penelitian adalah retrospective study. Jumlah sampel pada penelitian ini adalah 36 orang responden yang diambil dengan teknik purposive sampling yang memenuhi kriteria inklusi. Data penelitian diperoleh dari rekam medis pasien yang dirawat di ICU dari Januari sampai Agustus 2019 diruang rekam medis. Alat ukur yang digunakan lembar observasi untuk melihat karakteristik pasien, skor MSOFA pada hari pertama dan Clinical Pulmonary Infection Score (CPIS) pada hari ketiga. Hasil penelitian didapatkan mayoritas diagnosis medis responden bedah saraf $(44,4 \%)$, rerata untuk umur responden 52 tahun, rerata lama hari rawat 7 hari dan rerata lama pemakaian ventilator 85 jam 15 menit. Hasil analisis bivariat didapatkan nilai $\mathrm{r} 0,453, p$ value 0,006 lebih kecil dari nilai alpha 0,05 $(p$ value $<\alpha)$. Kesimpulan terdapat hubungan antara skor MSOFA dengan kejadian VAP dan berpola positif dimana semakin tinggi skor MSOFA maka akan semakin tinggi risiko terjadi VAP, pada pasien yang terpasang ventilator di ICU RSUD Arifin Achmad Provinsi Riau. Skor MSOFA dapat memprediksi kejadian VAP sehingga dapat memotivasi perawat untuk menggunakan skor MSOFA dalam mengobservasi kejadian VAP.
\end{abstract}

Kata kunci: VAP, skor MSOFA, CPIS.

\begin{abstract}
Multi-organ failure of patients hospitalized in ICU can increase the occurrence of Ventilator Associated Pneumonia (VAP). The purpose of this research was to see the Modified Sequential Organ Failure Assessment (MSOFA) score connection with VAP patient with ventilator attached. The design of this research was retrospective study. The number of samples in this study was 36 respondents taken with purposive sampling technique that meet the inclusion criteria. The data on this study was obtained from the medical records of patients treated in the ICU from January to August 2019 in the medical record room. Measuring instruments used in this research were the observation sheet to see the patient's characteristics, MSOFA scores on the first day and CPIS (Clinical Pulmonary Infection Score) on the third day. The results of this study obtained the majority of medical diagnosis of neurosurgical respondents (44.4\%), the center value for the respondents aged 52 years, the mid value of 7-day hospitalization and the middle value of the 85-hour and 15-minute ventilator usage length. The result of the Bivariate analysis obtained $r$ 0,453, $p$ value of 0.006 is smaller than the alpha value of $0.05(p<\alpha)$. Conclusion; there is a connection between MSOFA score with VAP and positive patterned where the higher the MSOFA score, then the higher the risk of VAP occurs in patients with ventilator attached in ArifinAchmad District Public Hospital's ICU in Riau. MSOFA scores can predict VAP events so as to motivate nurses to use MSOFA scores in observing VAP.
\end{abstract}

Keywords: VAP, MSOFA score, CPIS. 
Hetty Yuliana, Hellena Deli, Agrina, Hubungan Skor Modified Sequential Organ Failure Assessment (MSOFA) dengan Kejadian Ventilator Associated Pneumonia (VAP) pada Pasien yang terpasang Ventilator

\section{PENDAHULUAN}

Perkembangan ilmu dan teknologi saat ini sangat pesat, tuntutan terhadap rumah sakit untuk memberikan pelayanan kesehatan yang prima sangat besar. Rumah sakit merupakan institusi pelayanan perawatan kesehatan yang diberikan oleh tenaga kesehatan profesional seperti dokter, perawat, apoteker, ahli gizi dan tenaga kesehatan lainnya. Kegiatan ini bisa berdampak positif dan negatif, dampak positifnya dapat meningkatkan kesehatan masyarakat, sedangkan dampak negatifnya rumah sakit juga sebagai sumber berbagai macam penyakit, baik berasal dari pasien itu sendiri, perawat, dokter maupun pengunjung (Susanti, 2015). Penyakit infeksi yang terjadi setelah >48 jam dirawat dikenal dengan istilah Healthcare Associated Infections (HAIs) (Kementerian Kesehatan RI, 2011).

Jenis HAIs yang banyak dijumpai menurut Permenkes RI tahun 2017 diantaranya infeksi karena pemakaian ventilator yang dikenal dengan Ventilator Associated Pneumonia (VAP), Infeksi karena tindakan invasif seperti pemasangan infus (IAD), Infeksi yang disebabkan pemasangan kateter urine (ISK), dan Infeksi karena tindakan operasi (IDO). VAP infeksi yang sering ditemukan pada pasien Intensive Care Unit (ICU) dengan faktor risiko penggunaan alat bantu napas yang terjadi setelah $>48$ jam pemakaian ventilasi mekanik dengan pemakaian endotracheal tube (ETT) maupun tracheostomi (Susanti, 2015; Sari, 2019; \& Hipercci, 2017).

Pasien di ICU termasuk kelompok pasien berisiko sangat tinggi mengalami infeksi, dimana pasien yang dirawat di ICU mempunyai pertahanan tubuh yang menurun, terpasang berbagai alat invasif salah satunya ventilasi mekanik yang menyebabkan angka HAIs tinggi pada rawatan ICU (Permenkes, 2017).

Ventilasi mekanik merupakan alat bantu pernapasan bertekanan positif atau negatif untuk mempertahankan ventilasi dan pemberian oksigen dalam waktu lama (Smaltzer \& Bare, 2014; \& Hipercci, 2016). Pasien yang terpasang ventilasi mekanik dan ETT berisiko terjadinya infeksi pernapasan karena ETT yang terpasang menekan reflek epiglotik sehingga memudahkan masuknya bakteri virulen. Pemakaian ventilasi mekanik sering mengakibatkan komplikasi terjadinya VAP (Hipercci, 2016).

Kejadian VAP dimonitoring dengan Clinical Pulmonary Infection Score (CPIS) dengan cara mengambil data yaitu suhu tubuh pasien, leukosit yang meningkat, perubahan jumlah dan warna sputum, kadar oksigenisasi $\mathrm{PaO} 2 / \mathrm{FiO} 2$, dan pada gambaran rontgen memperlihatkan infiltrat baik yang baru atau sudah lama (Permenkes, 2017). Data ini diambil pada hari pertama rawatan sampai hari ketiga rawatan terpasang ventilasi mekanik, bila dihari pertama dan kedua 
pasien sudah terinfeksi maka dikategorikan pasien tidak termasuk infeksi HAIs, kecuali terjadi infeksi pada hari ketiga dan seterusnya baru dikategorikan HAIs. Keseluruhan data tersebut dijumlahkan berdasarkan kriteria yang ditetapkan terhadap masing-masing karaktristik CPIS (NHSN, 2019).

Kejadian VAP bisa diminimalkan dengan cara mengobservasi menggunakan skor Sequential Organ Failure Assessment (SOFA). Skor SOFA merupakan sistem penilaian yang menilai kinerja beberapa sistem organ dalam tubuh (Vincent et al, 1996). Skor SOFA menilai sistem organ dalam tubuh yang terdiri dari sistem respirasi, koagulasi, neurologi, hati, kardiovaskular, dan ginjal, namun menurut Taofik (2015), Grissom (2010), dan Kepmenkes RI (2017) sistem skoring SOFA sulit untuk diterapkan karena keterbatasan sumber daya dan meminimalkan pemeriksaan laboratorium.

Sistem skoring SOFA dimodifikasi menjadi Modified Sequential Organ Failure Assessment (MSOFA) oleh Grissom (2010) dengan melakuan penyederhanaan pada parameter yang dinilai yaitu pada fungsi hati, meniadakan fungsi koagulasi dan mengganti tekanan oksigen arteri $(\mathrm{PaO} 2)$ dengan saturasi oksigen arteri yang diukur dengan pulse oximeter (SpO2). Penilaian Skor MSOFA dilakukan sejak hari pertama pasien masuk ruang perawatan ICU dan dilakukan setiap hari. Penilaian ini diberi skor berdasar data yang diperoleh dengan rentang nilai 0 sampai
4, 0 untuk nilai normal tanpa kelainan sedangkan 4 menunjukkan nilai sangat abnormal (Grissom et al, 2010).

Survey awal yang dilakukan penulis pada RSUD Arifin Achmad, skor MSOFA belum dilakukan di ICU dan tidak terdapat Standar Prosedur Operasional (SPO) skor MSOFA pada ICU. Evaluasi disfungsi sistem organ pada rawatan ICU dapat memberikan informasi tentang prognosis penyakit pasien dan berhubungan dengan angka morbilitas dan angka mortalitas serta berkaitan dengan tingginya biaya di ICU (Isnaini, 2014).

Data yang didapat pada rekam medis di rumah sakit umum daerah yang ada di Pekanbaru tahun 2018 didapatkan rawatan pada ICU sebanyak 473 orang selama satu tahun, sedangkan jumlah pasien yang terpasang ventilator sebanyak 271 orang. Ini artinya $57 \%$ pasien memerlukan ventilasi mekanik. Angka kejadian infeksi karena penggunaan ventilator tahun 2017 di RSUD Arifin Achmad Provinsi Riau sebesar 13,07\% kejadian ini sedikit menurun tetapi tetap ada tiap tahunnya, sementara upaya untuk penurunan angka kejadian VAP sudah dilakukan berbagai cara diantaranya dengan bundle VAP (Sari, 2019).

Penelitian yang dilakukan oleh Grissom, tahun 2010 tentang skor MSOFA menyatakan bahwa skor MSOFA mudah diterapkan dengan parameter yang telah dimodifikasi. Penilaian MSOFA ini bisa di lakukan dengan penilaian data labor dan data 
Hetty Yuliana, Hellena Deli, Agrina, Hubungan Skor Modified Sequential Organ Failure Assessment (MSOFA) dengan Kejadian Ventilator Associated Pneumonia (VAP) pada Pasien yang terpasang Ventilator

klinis yang ada pada rekam medis, begitu juga dengan CPIS dapat mengidentifikasi VAP secara dini. Pencegahan terjadinya VAP dapat dilakukan dengan menggunakan bundle VAP (Lin et al, 2013).

Pelaksaan bundle VAP terdiri dari hand hygiene, elevasi tempat tidur $30-45^{\circ}$, oral hygine dengan clorhexidine 0,02\%, penghentian secara berkala agen sedasi dan penilaian kesiapan ekstubasi, peptic ulcer disease prophylaxis, dan deep vein trombosis prophylaxis (Permenkes, 2017; \& Futaci, 2013). Pelaksanaan bundle VAP sama pada semua pasien tetapi pada kenyataannya VAP masih juga terjadi terutama pada pasienpasien yang memiliki diagnosis kegagalan multi organ, karena penyebab VAP salah satunya kegagalan multi organ, dari uraian diatas penulis tertarik untuk melakukan penelitian dengan judul "Hubungan Skor Modified Sequential Organ Failure Assessment (MSOFA) dengan kejadian Ventilator Associated Pneumonia (VAP) pada pasien yang terpasang ventilator di ICU RSUD Arifin Achmad Provinsi Riau".

Penelitian ini bertujuan untuk membuktikan adanya hubungan skor Modified Sequential Organ Failure Assessment (MSOFA) dengan kejadian Ventilator Associated Pneumonia (VAP) pada pasien yang terpasang ventilator. Hasil penelitian diharapkan dapat dijadikan sebagai sumber informasi dalam pengembangan ilmu pengetahuan terutama tentang hubungan skor MSOFA dengan kejadian VAP pada pasien terpasang ventilator dan memotivasi perawat untuk mengobservasi pasien yang terpasang ventilasi mekanik dengan menggunaan skor MSOFA dan penilaian CPIS di ICU RSUD Arifin Achmad.

\section{METODE PENELITIAN}

Desain dalam penelitian ini menggunakan metode penelitian studi retrospektif (retrospective study). Penelitian dilakukan di RSUD Arifin Achmad Provinsi Riau yang merupakan rumah sakit rujukan provinsi Riau. Kegiatan dilakukan dari bulan Agustus sampai dengan Januari 2020. Populasi penelitian berjumlah 165 orang yaitu pasien yang pernah dirawat di ICU yang menggunakan ventilator dari bulan Januari sampai Agustus 2019. Sampel diambil dengan cara purposive sampling, dengan 36 responden. Alat pengumpul data menggunakan lembar observasi yang terdiri dari karakteristik responden, skor MSOFA dan CPIS. Data penelitian dianalisis dengan analisis univariat dan bivariat. Analisis univariat menggambarkan tentang responden yakni jenis kelamin, diagnosis medis, umur, lama dirawat di ICU, dan lama pemakaian ventilator. Uji statistik menggunakan uji Spearman correlation pada analisis bivariat untuk mengetahui keeratan dan arah hubungan skor MSOFA dengan kejadian VAP. 


\section{HASIL PENELITIAN}

\section{Analisis Univariat}

Analisis univariat berdasarkan karakteristik responden pada penelitian ini dapat dijelaskan pada tabel 1 .

Tabel 1

Distribusi responden berdasarkan jenis kelamin dan diagnosis medis

\begin{tabular}{lcc}
\hline \multicolumn{1}{c}{ Karakteristik } & $\begin{array}{r}\text { Jumlah } \\
(\mathrm{N}=36)\end{array}$ & $\begin{array}{c}\text { Persentase } \\
(\%)\end{array}$ \\
\hline Jenis kelamin & & \\
$\quad$ Laki-laki & 13 & 36,1 \\
$\quad$ Perempuan & 23 & 63,9 \\
Diagnosis Medis & & \\
$\quad$ Bedah saraf & 16 & 44,4 \\
Bedah umum & 6 & 16,7 \\
Bedah thorak kardiovaskular & 4 & 11,1 \\
Bedah onkologi & 8 & 22,2 \\
Badah urologi & 1 & 2,8 \\
Bedah gigi dan mulut & 1 & 2,8 \\
\hline
\end{tabular}

Tabel 1 diatas menunjukkan distribusi dari 36 responden penelitian, berdasarkan jenis kelamin didapatkan mayoritas berjenis kelamin perempuan yaitu sebanyak 23 responden $(63,9 \%)$, dan sebagian besar reponden diagnosis medis bedah saraf dengan 16 responden $(44,4 \%)$.

Tabel 2

Rata-rata umur, lama dirawat di ICU, lama pemakaian ventilator, skor MSOFA dan VAP

\begin{tabular}{|c|c|c|c|c|}
\hline Variabel & Mean & Median & Min & $\operatorname{Max}$ \\
\hline Umur (Tahun) & 47,42 & 52 & 18 & 67 \\
\hline $\begin{array}{l}\text { Lama dirawat di } \\
\text { ICU (Hari) }\end{array}$ & 8,39 & 7 & 4 & 24 \\
\hline $\begin{array}{l}\text { Lama pemakaian } \\
\text { ventilator (Jam) }\end{array}$ & 130,52 & 85,15 & 50,00 & 419,00 \\
\hline Skor MSOFA & 5,14 & 5 & 2 & 10 \\
\hline VAP (CPIS) & 3,06 & 3 & 1 & 8 \\
\hline
\end{tabular}

Tabel 2 didapatkan rata-rata umur responden 47,42 tahun (median $=52$ tahun). Rata-rata lama dirawat di ICU 8,39 hari (median $=7$ hari). Rata-rata lama pemakaian ventilator 130 jam 52 menit (median $=85$ jam 15 menit). Rata-rata skor MSOFA 5,14 dan nilai $($ median $=5)$. Rata-rata CPIS 3,06 (median $=3)$.

\section{Analisis Bivariat}

Analisis bivariat menggunakan uji spearman correlation karena data berdistribusi tidak normal. Pada penelitian ini ukuran pemusatan menggunakan median dan minimum-maksimum sebagai ukuran penyebaran.

Tabel 3

Hasil uji korelasi spearman skor MSOFA dengan VAP

\begin{tabular}{lcc}
\hline & & VAP \\
\hline Skor MSOFA & $\mathrm{r}$ & 0,453 \\
& $p$ & 0,006 \\
& $\mathrm{n}$ & 36 \\
\hline
\end{tabular}

Berdasarkan tabel 3 hasil uji Spearman correlation skor MSOFA dengan VAP didapatkan nilai $\mathrm{r}$ hasil 0,453 dan $p$ value $0,006<$ nilai alpha 0,05 ( $p$ value $<\alpha$ ) yang berarti H0 ditolak, maka dapat disimpulkan terdapat hubungan antara skor MSOFA dengan angka kejadian infeksi karena penggunaan ventilator. Berdasarkan hasil penelitian ini juga ditemukan terdapat hubungan yang sedang dan berpola positif 
Hetty Yuliana, Hellena Deli, Agrina, Hubungan Skor Modified Sequential Organ Failure Assessment (MSOFA) dengan Kejadian Ventilator Associated Pneumonia (VAP) pada Pasien yang terpasang Ventilator

dimana semakin tinggi skor MSOFA maka akan semakin tinggi risiko terjadi VAP.

\section{PEMBAHASAN}

\section{Analisis Univariat}

Hasil penelitian didapatkan responden berjenis kelamin perempuan 23 responden $(63,9 \%)$ lebih banyak dibandingkan dengan responden laki-laki. Hasil penelitian ini sejalan dengan penelitian Futaci (2013) yang dilakukan di ICU RSUP DR. Kariadi, diperoleh bahwa jumlah responden perempuan lebih banyak dibandingkan lakilaki, dengan jumlah perempuan adalah 58,5\% dan laki-laki 41,5\% dari 53 responden. Hasil penelitian berbeda didapatkan pada penelitian Isnaini (2014) yaitu pasien sepsis berjenis kelamin laki-laki sebanyak 27 responden (60\%) dari 45 responden. Perbedaan hasil penelitian ini menunjukkan perbedaan jenis kelamin tidak mempengaruhi risiko terjadi infeksi. Sargin (2013) juga mengemukakan gender tidak terlalu berpengaruh terhadap infeksi yang didapat karena penggunaan ventilator.

Pada penelitian ini, karakteristik responden didapatkan diagnosis medis bedah saraf terbanyak dengan 16 responden $(44,4 \%)$. Hasil penelitian Sari (2019) tentang pelaksanaan VAP bundle juga didapatkan diagnosis kasus terbanyak adalah kasus bedah sebanyak 23 responden $(69,7 \%)$, dan penelitian Sunaryo (2009) pada pasien sepsis didapatkan diagnosis medis bedah umum juga terbanyak dengan jumlah 66 orang $(50 \%)$ dari 132 responden. Hal ini berkaitan dengan pasien-pasien yang dilakukan bedah saraf berisiko mengalami gangguan pada saraf karena proses pembedahan terutama pada daerah pusat pernapasan yang bisa berakibat gagal napas. Pasien yang mengalami gagal napas akan memperlama pemakaian ventilator karena gagal weaning. Semakin lama pemakaian ventilator semakin tinggi risiko infeksi (Hipercci, 2016).

Pada penelitian ini juga didapatkan rerata responden berumur 52 tahun sedangkan umur termuda 18 tahun dan responden tertua berumur 67 tahun. Hasil ini sejalan dengan penelitian Nency (2015) tentang kejadian VAP, rata-rata umur pasien 49 tahun dengan umur minimal 14 tahun dan maksimal 78 tahun. Umur 46-55 tahun merupakan kelompok umur pada lansia awal menurut Depkes (2009), lansia lebih rentan terinfeksi karena proses perubahan tubuh dan sistem imun salah satunya perubahan sistem respirasi. Perubahan sistem respirasi pada lansia seperti perubahan struktur paru, penurunan dan kekakuan otot pernapasan, penurunan kemampuan batuk efektif yang membuat lansia lebih rentan terhadap infeksi respirasi (Smeltzer \& Bare, 2014).

Dari aspek lama dirawat di ICU didapatkan rerata 7 hari dan lama dirawat di ICU terendah 4 hari dan terlama 24 hari. Hasil 
ini sejalan dengan hasil penelitian Sunaryo (2009) pada pasien sepsis rata-rata lama perawatan 8,4 hari (11\%). Hasil penelitian Isnaini (2014) juga menunjukkan rata-rata lama hari rawatan pasien sepsis 9,36 hari. Lama hari rawatan ICU meningkatkan risiko infeksi karena perawatan ICU termasuk ruang rawatan dengan risiko sangat tinggi untuk kejadian infeksi, dimana pasien-pasien yang masuk ICU memiliki penyakit kritis dan komplek (Permenkes, 2017). Jadi semakin lama di ICU maka pasien semakin berisiko untuk infeksi.

Lama pemakaian ventilator juga mempengaruhi kejadian VAP dimana pada penelitian ini rerata lama pemakaian ventilator 85 jam 15 menit secara kontinu dan lama pemakaian ventilator terendah secara kontinu 50 jam dan tertinggi 419 jam. Hasil ini sejalan dengan penelitian yang dilakukan oleh Futaci (2013) dimana dari 53 responden didapatkan lama penggunaan ventilator $>48$ jam sebanyak 35 responden (66,04\%). Anton (2010) menyatakan bahwa pasien dengan penggunaan ventilator $>48$ jam lebih berisiko mengalami VAP, hal ini disebabkan pasien yang terpasang ventilator yang disambungkan ke ETT dapat menghambat respon batuk yang menyebabkan penumpukan sekret pada trakea. Pemasangan ETT juga menekan reflek epiglotik sehingga memudahkan masuknya bakteri virulen (Smeltzer \& Bare, 2014).

\section{Analisis bivariat}

Hasil uji Spearman correlation skor MSOFA dengan VAP terdapat hubungan antara skor MSOFA dengan kejadian infeksi karena penggunaan ventilator disalah satu rumah sakit rujukan yang ada di Pekanbaru Provinsi Riau. Berdasarkan hasil penelitian ini juga ditemukan terdapat hubungan yang sedang dengan nilai $\mathrm{r}$ 0,453 dan berpola positif yang artinya semakin tinggi skor MSOFA maka akan semakin tinggi risiko terjadi VAP. Hasil penelitian ini sejalan dengan penelitian Grissom (2010) didapatkan semakin tinggi skor MSOFA maka menunjukkan semakin kritis keadaan pasien tersebut. Penelitian Damanik (2019) juga menunjukkan skor SOFA merupakan instrumen yang digunakan dalam menilai tingkat keparahan serta prognosis penyakit pasien. Skor MSOFA menilai fungsi organ dalam tubuh yang terdiri dari fungsi neurologi, respirasi, kardiovaskular, hati, dan ginjal.

Indikator utama fungsi neurologi adalah tingkat kesadaran yang dinilai dengan GCS. Penurunan kesadaran salah satu efek dari pengeluaran cytokine dalam jumlah banyak yang menyebabkan terjadinya disfungsi neurologi (Virgiliu, 2014). Sedangkan kriteria dari weaning salah satunya status neurologis membaik dan penurunan kesadaran merupakan penyebab gagal dilakukan weaning ventilator (Hipercci, 2016). Gagal weaning berakibat penggunaan ventilator 
Hetty Yuliana, Hellena Deli, Agrina, Hubungan Skor Modified Sequential Organ Failure Assessment (MSOFA) dengan Kejadian Ventilator Associated Pneumonia (VAP) pada Pasien yang terpasang Ventilator

semakin lama berdampak terhadap kejadian VAP.

Disfungsi respirasi juga memperlama pemakaian ventilator disebabkan pasien yang mengalami penurunan oksigen secara terus menerus, peningkatan kadar karbondioksida, penurunan $\mathrm{pH}$ serta kegagalan multisistem yang mengarah pada gagal napas (Smeltzer \& Bare, 2014). Gagal napas yang terjadi pada pasien disfungsi respirasi menyebabkan pemakaian ventilator semakin lama yang meningkatkan risiko terjadinya VAP.

Gagal napas yang terjadi berakibat sel tidak mendapatkan oksigen dan nutrisi yang cukup dalam waktu lama akan berakibat kegagalan beberapa organ (Smeltzer \& Bare, 2014). Disfungsi organ meningkatkan risiko infeksi salah satunya disfungsi kardiovaskular. Disfungsi kardiovaskular awal ditandai dengan terjadinya hipovolemik berlanjut hipotensi, aritmia, perubahan frekuensi jantung, perfusi jaringan dan organ ditentukan oleh MAP (Smeltzer \& Bare, 2014). MAP rata-rata $80-120 \mathrm{mmHg}$ diperlukan untuk sel mendapat oksigen dan nutrisi. Nilai MAP $<70$ menjadikan kemampuan jantung untuk memompakan darah mengalami kerusakan sehingga perfusi jaringan terganggu. Pasien yang terpasang ventilator harus direncanakan melakukan weaning sedini mungkin untuk mencegah terjadi VAP, sedangkan kriteria weaning mengharuskan tekanan darah dalam batas normal.

Nilai MAP tidak stabil bahkan rendah akibat jantung gagal memompakan darah ke seluruh tubuh termasuk hati yang merupakan organ yang terkena dampak dari kegagalan sistem pada tubuh. Hati berfungsi memakan benda partikel (seperti bakteri) yang masuk melalui darah. Disfungsi hati menyebabkan perubahan fungsi metabolik yang ditandai dengan gejala klinis ikterik akibat peningkatan konsentrasi bilirubun dalam darah. Amonia merupakan produk metabolisme yang terjadi peningkatan karena disfungsi hati. Amonia serum dapat mengganggu fungsi sistem saraf pusat seperti encephalopati, koma hepatikum yang ditandai dengan penurunan kesadaran (Smeltzer \& Bare, 2014). Pasien yang mengalami penurunan kesadaran mengakibatkan gagal weaning ventilator. Pemakaian ventilator yang lama meningkatkan risiko kejadian VAP.

Indikasi pemakaian ventilator adalah pasien disfungsi respirasi yang mengalami penurunan oksigen secara terus menerus dan peningkatan kadar karbondioksida (Smeltzer \& Bare, 2014). Penurunan jumlah oksigen mengakibatkan kebutuhan oksigen jaringan perifer tidak tercukupi sehingga hipoperfusi. Hipoperfusi dalam waktu lama mengakibatkan disfungsi ginjal yang berdampak pada odema ekstremitas dan 
Jurnal Ners Indonesia, Vol.11 No.2, Maret 2021

capillary refill time (CRT) memanjang. Ginjal membantu mengatur metabolisme tubuh, sehingga gangguan ginjal akan mengenai setiap sistem tubuh (Virgiliu, 2014). Manifestasi klinik disfungsi ginjal pada paruparu seperti sesak napas dan batuk berdahak. Disfungsi ginjal juga mengakibatkan asidosis yang memerlukan koreksi salah satunya dengan ventilasi mekanik (Wijaya \& Putri, 2013). Komplikasi yang sering terjadi pada pasien terpasang ventilator adalah VAP (Hipercci, 2016).

Kejadian VAP dimonitoring dengan CPIS yang terdiri dari: suhu, jumlah leukosit, sekresi trakea, kadar oksigenisasi $\mathrm{PaO} 2 / \mathrm{FiO} 2$, dan foto thoraks (NHSN, 2019). Demam merujuk pada peningkatan suhu tubuh diakibatkan infeksi atau peradangan, demam terjadi sebagai respon terhadap infeksi dimana masuknya mikroba (Sherwood, 2016). Peningkatan suhu tubuh pada kejadian VAP menandakan tubuh melakukan perlawanan terhadap bakteri yang masuk kedalam tubuh.

Pasien yang mengalami infeksi, tubuh akan melakukan perlawanan dengan mengaktivasi leukosit untuk mengeluarkan bakteri dari tubuh. Teraktivasinya leukosit menyebabkan pengeluaran cytokine dalam jumlah banyak yang tidak baik efeknya bagi tubuh. Efek yang ditimbulkan antara lain penurunan fungsi cerebral, fungsi paru, fungsi hati, fungsi kardiovaskular, dan fungsi renal (Virgiliu, 2014).
Gangguan fungsi paru memerlukan penggunaan ventilator. Pasien yang terpasang ventilator yang disambungkan ke ETT reflek batuk ditekan karena penutupan glotis dihambat yang menyebabkan penumpukan sekret pada trakea dan memudahkan masuknya bakteri virulen. Jumlah sputum yang banyak menandakan masuknya bakteri penyebab infeksi (Smaltzer \& Bare, 2014).

Tubuh yang mengalami infeksi terjadi peningkatan metabolisme sehingga terjadi peningkatan konsumsi oksigen dalam tubuh yang berakibat kebutuhan oksigen tidak mencukupi (Virgiliu, 2014). Pasien yang mengalami penurunan oksigen secara terus menerus, akan terjadi peningkatan kadar karbondioksida yang mengakibatkan ketidakseimbangan asam basa (Smaltzer \& Bare, 2014). Infeksi pneumonia oleh bakteri merupakan salah satu faktor penyebab terjadinya Acute Respiratory Distress Symdrome (ARDS) yang terpasang ventilasi mekanik.

Pasien yang menggunakan ventilasi mekanik dilakukan pemeriksaan foto thoraks untuk menunjukkan proses patologi ekstensif dalam paru-paru (Smaltzer \& Bare, 2014). Gambaran radiologi pada pneumonia dapat berupa bercak-bercak, dan sering memperlihatkan infiltrat baik pada satu atau beberapa lobus (Wijaya \& Putri, 2013). 
Hetty Yuliana, Hellena Deli, Agrina, Hubungan Skor Modified Sequential Organ Failure Assessment (MSOFA) dengan Kejadian Ventilator Associated Pneumonia (VAP) pada Pasien yang terpasang Ventilator

\section{SIMPULAN}

Penelitian yang telah dilakukan dari tanggal 23 Oktober sampai 7 November 2019 tentang hubungan skor MSOFA dengan kejadian VAP pada pasien yang menggunakan ventilator secara kontinu berjumlah 36 responden. Hasil univariat didapatkan bahwa mayoritas responden menurut jenis kelamin didapatkan 23 responden perempuan $(63,9 \%)$. Mayoritas responden menurut diagnosis medis adalah bedah saraf dengan 16 responden $(44,4 \%)$. Rerata pada skor MSOFA 5 dengan skor MSOFA terendah 2 dan yang tertinggi 10 . Rerata CPIS 3 dengan CPIS terendah 1 dan CPIS tertinggi 8 .

Hasil analisis bivariat dengan uji spearman correlation didapatkan nilai r $0,453, \quad p$ value $(0,006)<\alpha(0,05)$ yang berarti H0 ditolak, maka dapat disimpulkan bahwa hubungan antara skor MSOFA dengan kejadian VAP pada pasien yang terpasang ventilator didapatkan hubungan yang sedang dan berpola positif dimana semakin tinggi skor MSOFA semakin berisiko VAP.

\section{SARAN}

Hasil penelitian ini memotivasi perawat untuk mengobservasi pasien yang terpasang ventilasi mekanik dengan menggunaan skor MSOFA dan penilaian CPIS di ICU RSUD Arifin Achmad karena terdapat hubungan antara skor MSOFA dengan kejadian VAP.
Bagi penelitian yang akan datang, hasil penelitian ini sebagai sumber informasi dasar, evidence based, referensi penelitian lebih dalam lagi tentang skor MSOFA dan kejadian VAP pada pasien terpasang ventilator dengan menggunakan CPIS dan melakukan penelitian dengan desain penelitian studi prospektif (cohort) dengan waktu penelitian yang panjang dan sampel yang besar.

\section{DAFTAR PUSTAKA}

Anton, Y. P., \& Hooper, D. C. (2010). Acquired infections dueto gramnegative bacteria. M. D. Hospital. $N$ Engl J Med, 362, 1804-13.

Center for Disease Control and Prevention. (2019). National healthcare safety network (NHSN) patient safety component manual. Pneumonia (Ventilator-Associated [VAP] and NonVentilator-Associated Pneumonia [PNEU]) Event, 6-6.

Damanik, S. R. H., Utami, G. T., Nurcahyati, S., \& Safri. (2019). Organ failure of patients using ventilator based on the sequence organ failure assessment score (SOFA) admitted in Intensive Care Unit. Diperoleh tanggal 30 Maret 2019

dari: https://www.ncbi.nlm.nih.gov/pubmed/ 30718205.

Data Rekam Medis RSUD Arifin Achmad Provinsi Riau Januari sampai Agustus 2019.

Depkes RI (2009). Profil kesehatan Indonesia. Diperoleh tanggal 28 November 2019 dari: www.depkes.go.id/resources/download/ ..../profil-kesehtan-indonesia-2009.pdf.

Futaci, D. A. (2013). Penggunaan ventilator bundle pada pasien dengan ventilator mekanik di ICU RSUP DR. Kariadi periode Juli-Desember 2013. Diperoleh tanggal 30 Maret 2019 dari: 
https://www.ncbi.nlm.nih.gov/pubmed/ 30718205.

Grissom, C. K., Brown, S. M., Kuttler, K. G., Boltax, J. P., Jones, J., Jephson, A. R., \& Orme Jr, J. F. (2010). A modified sequential organ failur assessment (MSOFA) score for critical care triage. NIH Public Access. https://doi.org/10.1001/dmp.2010.40.A. Diperoleh tanggal 8 April 2019 dari: https://www.ncbi.nlm.nih.gov/pmc/artic les/PMC3811929/pdf/nihms519811.pdf.

Hipercci. (2016). Modul pelatihan keperawatan intensif dasar. Jakarta: In Media.

Isnaini, N. A. (2014). Korelasi antara skor sofa dengan lama rawat inap pasien sepsis di ICU RSUP Dr. Kariadi Semarang. Diperoleh tanggal 3 Maret 2019 dari: http://eprints.undip.ac.id/44858/.

Kementerian Kesehatan RI. (2011). Pedoman pencegahan dan pengendalian infeksi di rumah sakit dan fasilitas pelayanan kesehatan lainnya kesiapan menghadapi emerging infectious disease. Jakarta: Kemenkes RI.

Keputusan Menteri Kesehatan RI. (2017). Pedoman nasional pelayanan kedokteran tata laksana sepsis. Jakarta: Menkes RI.

Lin, L. M., Oh, H., Chuin, S., Chng, F., Lay, L. S., Yin, C. Y., \& Bien, M. H. K. (2013). Guidelines for the prevention of ventilator associated pneumonia. Singapure: Singapure General Hospital.

Nency, C. (2015). Gambaran kejadian ventilator-associated pneumonia pada pasien yang dirawat di ICU dan CVCU RSUD Arifin Achmad periode Januari s/d Agustus 2014. Jurnal Online Mahasiswa Fakultas Kedokteran (JOMFK), 2(2), 1-9.

Peraturan Menteri Kesehatan RI. (2017). Pedoman pencegahan dan pengendalian infeksi di fasilitas pelayanan kesehatan. Jakarta: Permenkes RI.

Sargin, F., Sagiroglu, A. E., Dogru, A., Gura, M., Sayhan, H., \& Tigen, E. (2013).
Etiologi, Incidence and factors of ventilator associated pneumonia in an intensive care unit of training and research hospital in Istambul. Gastape Research and Training Hospital, Infection Disease and Clinical Mocrobiology Departement, Anasthesiology and Reanimation Dapartement. Gastape Tip Dergisi, 28(1), 8-14.

Sari, N., Deli, H., \& Agrina (2019). Gambaran pelaksanaan vap bundle (Vapb) pada pasien yang terpasang ventilator. Jurnal Online Mahasiswa Fakultas Keperawatan (JOMFKp), 6(1), 19-27.

Sherwood, L. (2016). Fisiologi manusia dari sel ke sistem. (ed. ke-8). Jakarta: EGC.

Smaltzer, S. C., \& Bare, B. G. (2014). Keperawatan medikal bedah Brunner \& Suddarth. (ed. ke-12 vol. ke-1). Jakarta: EGC.

Smaltzer, S. C., \& Bare, B. G. (2014). Keperawatan medikal bedah Brunner \& Suddarth. (ed. ke-12 vol. ke-2). Jakarta: EGC.

Sunaryo, A. (2009). Perbandingan validasi APACHE II dan SOFA score untuk memperkirakan mortalitas pasien yang dirawat di Ruang Perawatan Intensif. Diperoleh tanggal 26 November 2019 dari:http://perdici.org/wpcontent/upload s/mkti.

Susanti, E. (2015). Identifikasi faktor resiko kejadian infeksi nosokomial pada pasien yang terpasang ventilator di ruang intensive care. Jurnal Online Mahasiswa Program Studi Ilmu Keperawatan (JOMPSIK), 2(1), 590599.

Taofik, S. (2015). Perbandingan validitas sistem skoring apache II, sofa, dan customized sequential organ failure assessment (Csofa) untuk memperkirakan mortalitas pasien nonbedah yang dirawat di ruang perawatan intensif. Jurnal Anestesiologi Indonesia, 7(2), 102-113.

Vincent, J. L., Moreno, R., Takala, J., Willatts, S., Mendonca, A. D., Bruining, H., Reinhart, C. K., Suter, P. M., \& 
Hetty Yuliana, Hellena Deli, Agrina, Hubungan Skor Modified Sequential Organ Failure Assessment (MSOFA) dengan Kejadian Ventilator Associated Pneumonia (VAP) pada Pasien yang terpasang Ventilator

Thijs, L. G.. (1996). The SOFA (Sepsis related Organ Failure Assessment) score to describe organ dysfunction / failure On behalf of the Working Group on Sepsis. Intensive Care Med. 22, 707710.

Virgiliu, P. (2014). Molecular mechanisms in the pathogenesis of sepsis. Journal of Medicine and Life, 7(2), 38-41.

Wijaya, A. S., \& Putri, Y. M. (2013). KMB 1. Keperawatan medikal bedah. Keperawatan dewasa teori dan contoh ASKEP. Yogyakarta: Nuha Medika. 